\title{
Extrémní víceletá hydrologická sucha v povodí Labe
}

\section{LADISLAV KAŠPÁREK, ROMAN KOŽíN}

Klíčová slova: víceleté hydrologické sucho - Labe - nedostatkový objem - extrémy

\section{SOUHRN}

Předmětem studie bylo zhodnocení víceletých období hydrologického sucha na povodí Labe v Děčíně (plocha povodí 51104 km²). Pro vodoměrnou stanici v tomto profilu je k dispozici řada průměrných měsičních průtoků z let 1851-2020. Pro toto období jsme z několika datových zdrojů sestavili řady průměrných srážek a prưměrných teplot na ploše povodí. Z měsíčních řad byly vypočítány roční výšky srážek, roční výšky odtoku a rozdíly ročních výšek srážek a odtoků. Pro tyto veličiny byly vypočteny dlouhodobé průměry a regresní lineární trendy pro změnu v čase; u všech tří veličin jsou velmi mírně vzestupné, podstatnější je zejména dlouhodobé kolísání srážek. Podle vyčíslených víceletých průměrných průtoků a srážek jsme vyhledali a sloučili prípady, ze kterých se generuje jedno souvislé sucho o trvání minimálně pěti let pro srážky i pro odtoky. Pro jednotlivé periody sucha jsme vypočítali nedostatkové objemy. Jako mezní průtok byl zvolen dlouhodobý průměrný průtok. Hydrologické sucho 2013-2020 mělo nejdelší trvání - téměř sedm let - ze všech období sucha od roku 1851 a také se vyznačuje největším celkovým nedostatkovým objemem. Při posouzení podle průměrného ročního nedostatkového objemu je až čtvrté v pořadí. Při porovnání časových průběhů měsíčních průtoků se ukázalo, že prípady z různých období mají podobný průběh.

\section{ÚVOD}

V publikaci [1] byla podrobně zpracována problematika hydrologického sucha na území České republiky, včetně výpočtu nedostatkových objemů od roku 1851 na Labi v Děčíně. Toto zpracování bylo zaměřeno na hydrologická sucha, při kterých byl podkročen průměrný měsíční průtok s pravděpodobností prekročení 95 \%, což znamená sucha trvající několik měsíců. Publikace [2] mapuje výskyt za posledních 500 let a z toho podrobněji zpracované období od roku 1961 do současnosti. Po výskytu hydrologického sucha v roce 2015, zhodnoceného ve studii [3], byla z podnětu Povodí Vltavy, s. p., v práci [4] podle rekonstrukce historické raady průtoků k profilu vodoměrné stanice Kamýk od roku 1890 do roku 2011 zhodnocena hydrologická sucha v povodí Vltavské kaskády. Období sucha 2014-2018 bylo předmětem referátů semináře, viz [5]. Poznatky o výskytu extrémních nízkých vodních stavů na Labi v období 1919-2015 zveřejnil Elleder [6].

Předkládaná studie se zabývá hydrologickými suchy v letech 1851-2020 na Labi v Děčíně, jejichž trvání je několik let, takže jsou charakterizována výskytem minimálních několikaletých průměrných odtoků. Podnětem k jejímu zpracování bylo dlouhodobé sucho, jež začalo v roce 2013 a skončilo v roce 2020. Cílem práce bylo porovnat toto hydrologické sucho se srovnatelnými historickými prrípady a ukázat na jeho podobnosti a odlišnosti i v souvislosti s probíhajícím oteplováním.
V článku jsou termíny srážky, odtok, výpar a evapotranspirace použity ve významu průměrných výšek vody na povodí v mm.

\section{METODIKA}

\section{Data}

Datové soubory srážek, průtoků Labe v Děčíně a průměrných teplot vzduchu na povodí Labe po Děčín byly převzaty z podkladů sestavených při zpracování článku [7]. Tato data byla doplněna, částečně i podle podkladů dostupných v současné době vyměněna. Přidány byly srážky, teploty vzduchu i průtoky do roku 2020. Výměna proběhla u průtoků pro období od roku 1980 za dnes platné odovlivněné, tj. pozorování prưtokủ byla očištěna o manipulace nádrží, odběry a vypouštění odpadních vod. Pro léta 1954-1979, kdy průtoky již byly ovlivněny manipulacemi Vltavské kaskády a odovlivněné průtoky nejsou zpracovány, byla použita data ze zprávy [4] a posouzena míra ovlivnění průtoků Vltavy v profilu Zbraslav.

Řady měsičních hodnot od hydrologického roku 1851 do roku 2020 obsahují data za 170 let. V průběhu zpracování studie skončilo hydrologické sucho, které začalo koncem roku 2013. Pro jeho zhodnocení byly řady průtoků, srážek a teplot vzduchu doplněny o aktuálně dostupná data, jež nemusejí přesně odpovídat budoucímu definitivnímu vyhodnocení. Pro posouzení dlouhodobé proměnlivosti srážek byla použita i data z období 1801-1850. Srážky jsou odhadnuty podle pozorování z Klementina, od roku 1829 doplněné o pozorování v Havlíčkově Brodě a od roku 1848 v Čáslavi. Spolehlivost odhadu srážek je tedy malá až do roku 1876. Od té doby jsou k dispozici data z 55 stanic a od roku 1880 z 382 srážkoměrných stanic.

Pro porovnání prípadů víceletých období hydrologického sucha byly použity zejména jejich trvání, celkové nedostatkové objemy a průměrné nedostatkové objemy. Nedostatkové objemy byly vypočítány jako součet rozdílů průměrného měsíčního odtoku a odtoku v daném měsíci za celé období sucha; měsíce, kdy odtok byl větší, se nezapočítávají.

\section{Dlouhodobé průměry a trendy}

Z měsičních řad byly vypočitány roční výšky srážek, roční výšky odtoku a rozdíly ročních výšek srážek a odtoků. Pro tyto veličiny byly vypočteny dlouhodobé průměry a regresní lineární trendy pro změnu v čase v období 1851-2020 (tab. 1). 


\section{Významné prípady víceletého sucha}

Identifikace výskytů srážkových a odtokových významných prípadů víceletého sucha byla provedena následovně:

- Byly vypočteny průměry z ročních výšek odtoku a z ročních výšek srážek pro periodu průměrování jeden rok až šest let z celých řad 1851-2020. Hodnoty $\checkmark$ šesti souborech zprůměrovaných odtoků a zprůměrovaných srážek byly setříděny od nejmenší po největší. Následně k nim byl prǐřazen rok, který udává konec intervalu průměrování a pořadí v setříděném souboru.

- Dále byl vyhledán približný časový rozsah nejvýznamnějších víceletých období sucha. Z tabulky setříděných 20 minimálních víceletých prưměrných průtoků a srážek byly vyhledány a sloučeny případy, z nichž se generuje jedno souvislé sucho o trvání minimálně pět let pro srážky i pro odtoky. Byly tak získány letopočty počátků a konců epizod sucha (obr. 1).

- Detailněji byly epizody hydrologického sucha vymezeny tak, že začátek období každého prípadu sucha byl prisouzen měsíci, kdy na dlouhou následující dobu odtoky poklesly pod dlouhodobý průměrný odtok 15,74 mm/měsíc, vypočítaný z celé řady 1851-2020. Inverzní podmínka byla použita pro stanovení měsíce ukončení sucha. Vzhledem k tomu, že se jedná o víceletá období sucha, jsou považovány krátké úseky obvykle dlouhé jeden až dva měsíce, maximálně čtyři měsíce, ve kterých odtok byl větší než porovnávací hodnota prưměrného průtoku, za součást pokračujícího sucha.

- Porovnání suchých období bylo provedeno dle velikosti nedostatkového objemu.

\section{VÝSLEDKY A DISKUZE}

Dlouhodobé trendy všech tří veličin z tab. 1 jsou vzestupné a statisticky nevýznamné. Při přepočtu na průměry za celou délku řad jsou v rozmezí 2,8 \% až $8,2 \%$. Součet zvětšení u odtoku a u rozdílu odtoku a srážek v absolutních hodnotách je o 2 mm/rok větší než zvětšení srážek.

Všechny tři veličiny kolísají nejen meziročně, ale i dlouhodobě, což ukazuje průběh desetiletých klouzavých prưměrư na obr. 2. Srážky mají v obdobi cca 1871-1977 průběh vlny s postupným vzestupem a následujícím poklesem, který však není tak hluboký, jako byl v desetiletích kolem roku 1871. Na průběhu srážek je tendence $k$ dlouhodobé periodicitě patrná i v předcházejícím období. V řadě odtoků je od období minim kolem roku 1953 patrný vzestup, od roku 1988 pokles, jenž neodpovídá průběhu srážek a Ize jej přisoudit intenzivnímu zvyšování teplot vzduchu. Rozdíl srážek a odtoku, který lze považovat za územní výpar, se od desetiletí končícího rokem 1991 zvětšuje.

Režim výskytu víceletých minimálních srážek a následně i ročních a víceletých minimálních odtoků tedy $v$ dlouhodobém měřítku značně kolísá (obr. 2). Pouze v letech 1930-1935 se vymezení srážek a odtoků neshodují. V tomto období se vyskytla v použitém výběru jen jedna dvouletá minimální srážka a žádná šestiletá minimální srážka. Odtoková minima z tohoto období byla způsobena srážkovým minimem jenom třiletého trvání, které se při použitém

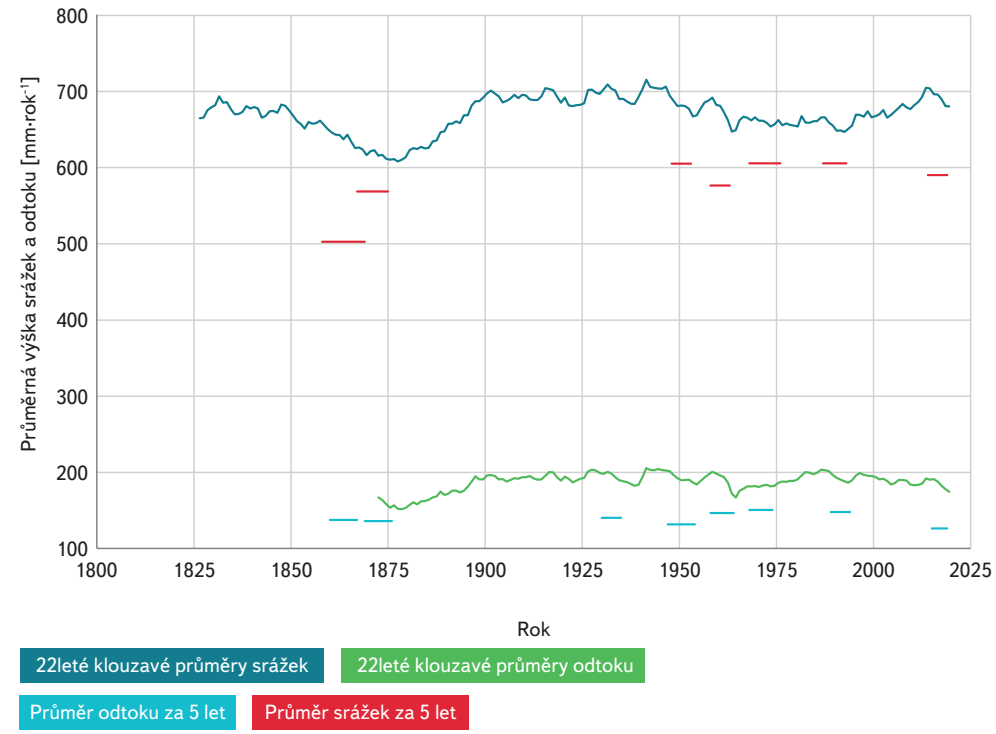

Obr. 1. 22leté klouzavé prưměry srážek (tmavě modrá) a odtoků (zeleně). Přibližné časové vymezení výskytu víceletých minimálních srážek (červeně) a odtoků (modře) Fig. 1. 22-year moving averages of precipitation (dark blue) and runoff (green). Approximate time determination of multi-annual minimum precipitation (red) and runoff (blue)

postupu výběru nezobrazí. Obr. 2 dokládá, že v období větších 22letých průměrných výšek srážek se víceleté minimální srážky nevyskytly. Pro průměrování byl použit interval 22 let, jenž odpovídá periodicitě, která byla nalezena v řadě použitých srážek i v řadě průtoků Vltavy, viz [8].

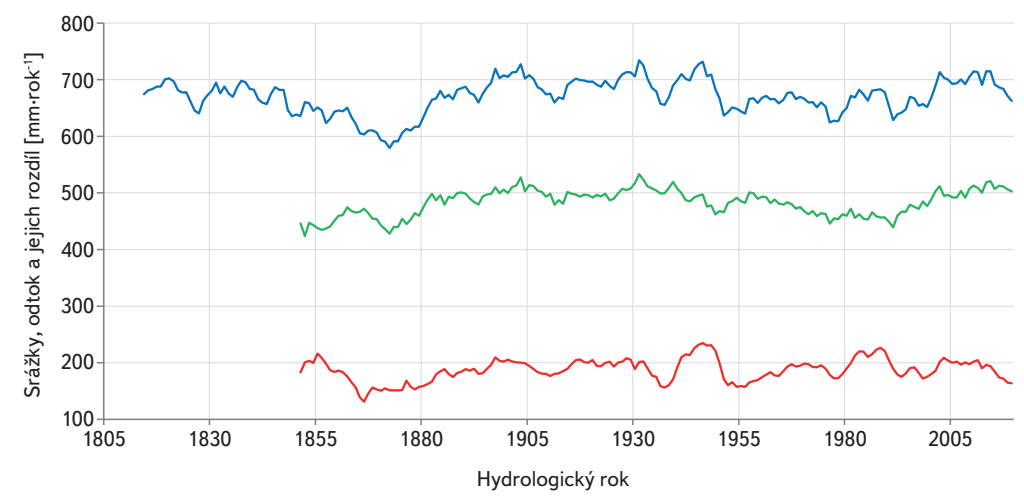

Obr. 2. Desetileté klouzavé průměry ročních výšek srážek (modře), odtoků (červeně) a rozdílů srážek a odtoků (zeleně) pro povodí Labe v Děčíně 1805-2019

Fig. 2. Ten-year moving averages of annual precipitation (blue), runoff (red) and differences in precipitation and runoff (green) in the Elbe basin in Děčín (1805-2019)

Tab. 1. Dlouhodobé průměry a trendy srážek, odtoků a jejich rozdillů

Tab. 1. Long-term averages and trends of precipitation, runoff and their differences

Veličina Regresní koeficient Změna za 170 let [mm] Průměr za 170 let [mm/rok]

\begin{tabular}{lcccc}
\hline Srážky & 0,160 & 27,0 & 669,6 & 4,04 \\
\hline $\begin{array}{l}\text { Rozdíl srážek } \\
\text { a odtoků }\end{array}$ & 0,0822 & 13,9 & 483,7 & 2,87 \\
\hline Odtoky & 0,0895 & 15,1 & 185,9 & 8,14
\end{tabular}


Tab. 2. Charakteristiky trvání a nedostatkových objemů víceletých období hydrologického sucha

Tab. 2. Characteristics of duration and deficit volumes of multi-annual hydrological droughts

\begin{tabular}{|c|c|c|c|c|c|c|c|c|c|c|}
\hline \multirow{2}{*}{ Období } & \multirow{2}{*}{$\begin{array}{l}\text { Začátek } \\
\text { Měsíc }\end{array}$} & \multirow{2}{*}{$\begin{array}{l}\text { Konec } \\
\text { Měsíc }\end{array}$} & \multirow{2}{*}{$\begin{array}{l}\text { Trvání } \\
\text { Měsíců }\end{array}$} & \multicolumn{2}{|c|}{$\begin{array}{l}\text { Nedostatkový } \\
\text { objem [mm] }\end{array}$} & \multirow{2}{*}{$\begin{array}{l}\text { Minimální } \\
\text { odtok } \\
\text { [mm/měsíc] }\end{array}$} & \multicolumn{2}{|c|}{ Výskyt minima } & \multicolumn{2}{|c|}{ Přerušení } \\
\hline & & & & Celkem & Roční & & Měsíc & Rok & Počet & $\begin{array}{l}\text { Objem } \\
\text { [mm] }\end{array}$ \\
\hline 1862-1866 & 4 & 11 & 56 & 380 & 81,5 & 3,5 & 8 & 1963 & 4 & 40,8 \\
\hline 1871-1876 & 6 & 10 & 53 & 348 & 78,7 & 2,93 & 10 & 1874 & 5 & 21,2 \\
\hline 1932-1936 & 8 & 1 & 42 & 204 & 58,3 & 3,45 & 8 & 1934 & 7 & 40 \\
\hline 1948-1954 & 4 & 6 & 75 & 306 & 48,9 & 2,66 & 2 & 1954 & 14 & 84,5 \\
\hline 1962-1964 & 7 & 10 & 28 & 193 & 82,7 & 4,81 & 7 & 1964 & 0 & 0 \\
\hline 1971-1974 & 1 & 10 & 46 & 217 & 55,5 & 5,01 & 9 & 1973 & 2 & 2,6 \\
\hline 1989-1993 & 5 & 11 & 55 & 241 & 52,5 & 3,12 & 8 & 1992 & 9 & 48,5 \\
\hline $2013-2020$ & 7 & 6 & 84 & 437 & 63,2 & 2,33 & 9 & 2019 & 9 & 44 \\
\hline
\end{tabular}

Z údajů tab. 2 a obr. 3 a 4 vyplývá, že hydrologické sucho 2013-2020 mělo nejdelší trvání - téměř sedm let - ze všech období sucha od roku 1851 a také se vyznačuje největším celkovým nedostatkovým objemem. Při posouzení podle průměrného ročního nedostatkového objemu je ale až čtvrté v pořadí. Mimořádnou délku trvání mělo i víceleté sucho 1948-1954, jeho prưměrný roční nedostatkový objem je však z posuzovaných prípadů nejmenší. Pro periody sucha 1962-1964 a 1971-1974, vyhodnocené podle průtoků neočištěných o ovlivnění, jsme podle dat ze studie [5] posoudili vliv Vltavské kaskády na průtoky Vltavy. Ukázalo se, že v obou uvedených obdobích se nadlepšování průtoků uskutečnilo jen v rámci sezonního hospodaření nádrží. Průměry průtoků za celá období sucha tedy nebyly znatelně ovlivněny. Jelikož manipulace Vltavské kaskády jsou i pro průtoky Labe v Děčíně nejpodstatnějším ovlivněním, ponechali jsme výsledky hodnocení pro uvedené prípady sucha nezměněné.

Na obr. 5 a 6 jsou vyneseny průběhy měsíčních výšek odtoku v rozsahu let s výskytem sucha, které jsou si navzájem nápadně podobné. U period 1948-1954 a 2013-2020 je to o to zajímavější, že jsou od sebe značně vzdáleny. Základní vlastností je periodické kolísání odpovídající zvětšení zvýšení odtoku v zimních a jarních měsících. Sucho při námi zvoleném vymezení jeho začátku začíná obvykle v období od dubna do července, nejčastěji končí v říjnu a listopadu.

Víceletá sucha mají podobný průběh v počátečním a následujících dvou letech. Na rozmezí třetího a čtvrtého roku se obvykle odtok zvýší tak, že sucho skončí.

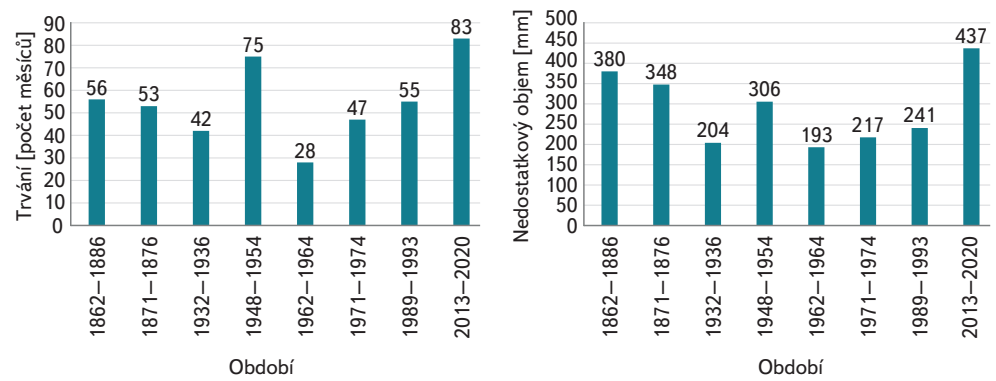

Obr. 3. Trvání sucha v měsících (vlevo) a celkový nedostatkový objem v období sucha v mm (vpravo)

Fig. 3. Drought duration in months (left) and total deficit volume in drought periods in $\mathrm{mm}$ (right)

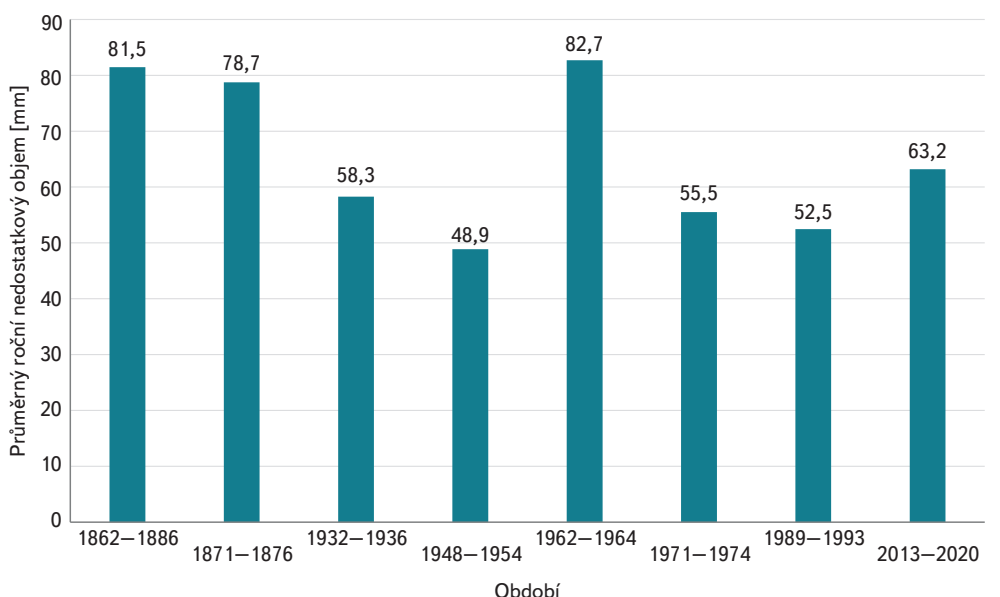

Obr. 4. Průměrný roční nedostatkový objem v mm Fig. 4. Average annual deficit volume in $\mathrm{mm}$
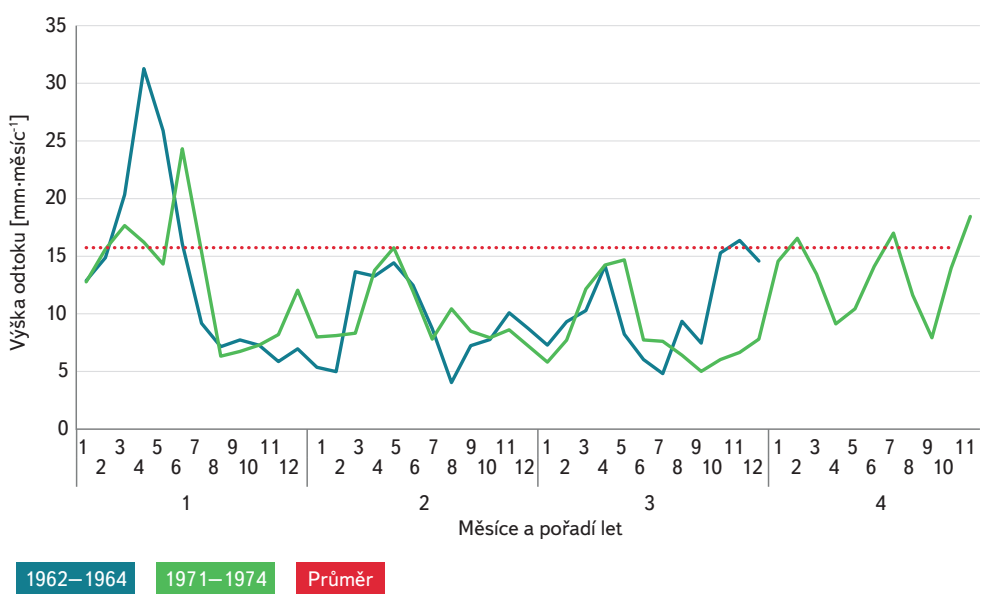

Obr. 5. Porovnání průběhu odtoku u period sucha 1962-1964 a 1971-1974 Fig. 5. Comparison of runoff patterns during drought periods 1962-1964 and 1971-1974 
Tab. 3. Charakteristiky hydrologické bilance v obdobich viceletého sucha - prüměrné roční hodnoty

Tab. 3. Characteristics of the hydrological balance in periods of multi-annual drought-average annual values

\section{Období Srážka [mm] Odtok [mm] Srážka - odtok [mm] Potenciální evapotranspirace [mm] Teplota vzduchu [ $\left.{ }^{\circ} \mathrm{C}\right]$}

\begin{tabular}{|c|c|c|c|c|c|}
\hline 1862-1866 & 513 & 110 & 403 & 581 & 7,43 \\
\hline 1871-1876 & 623 & 105 & 518 & 581 & 7,35 \\
\hline 1932-1936 & 570 & 119 & 451 & 546 & 7,48 \\
\hline 1948-1954 & 634 & 131 & 503 & 584 & 7,78 \\
\hline 1962-1964 & 594 & 106 & 488 & 593 & 7,28 \\
\hline 1971-1974 & 588 & 131 & 457 & 574 & 7,53 \\
\hline 1989-1993 & 609 & 126 & 483 & 611 & 8,38 \\
\hline 2013-2020 & 616 & 122 & 494 & 624 & 9,16 \\
\hline průměr & 593 & 119 & 475 & 587 & 7,80 \\
\hline minimum & 513 & 105 & 403 & 546 & 7,28 \\
\hline maximum & 634 & 131 & 518 & 624 & 9,16 \\
\hline
\end{tabular}

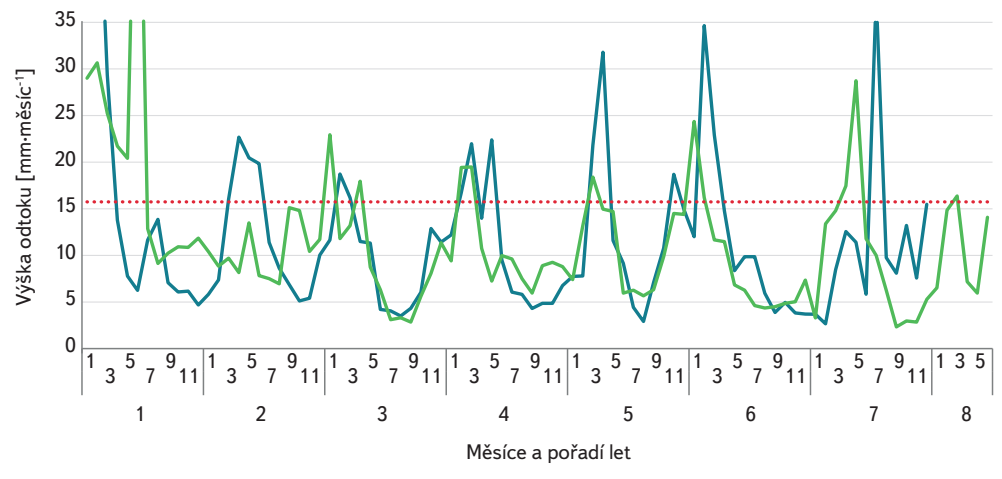

\section{8-1954 2013-2020 Prưmèr}

Obr. 6. Porovnání průběhu odtoku u period sucha 1948-1954 a 2013-2020

Fig. 6. Comparison of runoff patterns during drought periods 1948-1954 and 2013-2020
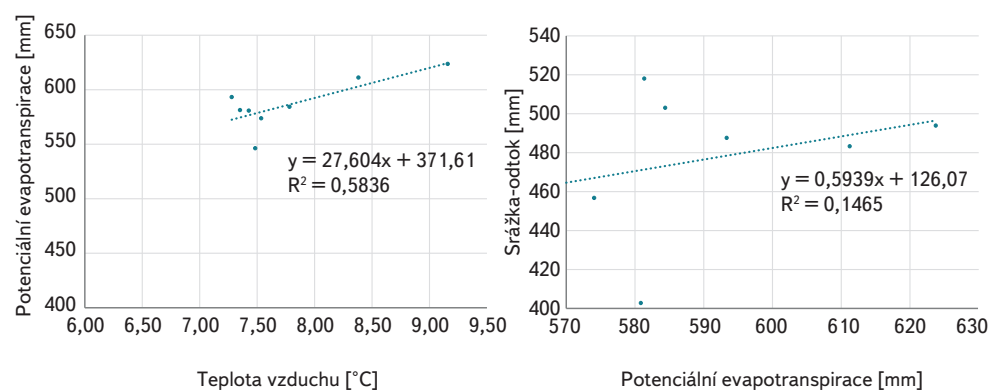

Obr. 7. Vztah potenciální evapotranspirace (PET) a teploty vzduchu (vlevo) a vztah územního výparu (srážka - odtok) a PET

Fig. 7. Relationship between potential evapotranspiration (PET) and air temperature (left) and relationship between evapotranspiration (precipitation - runoff) and PET (right)

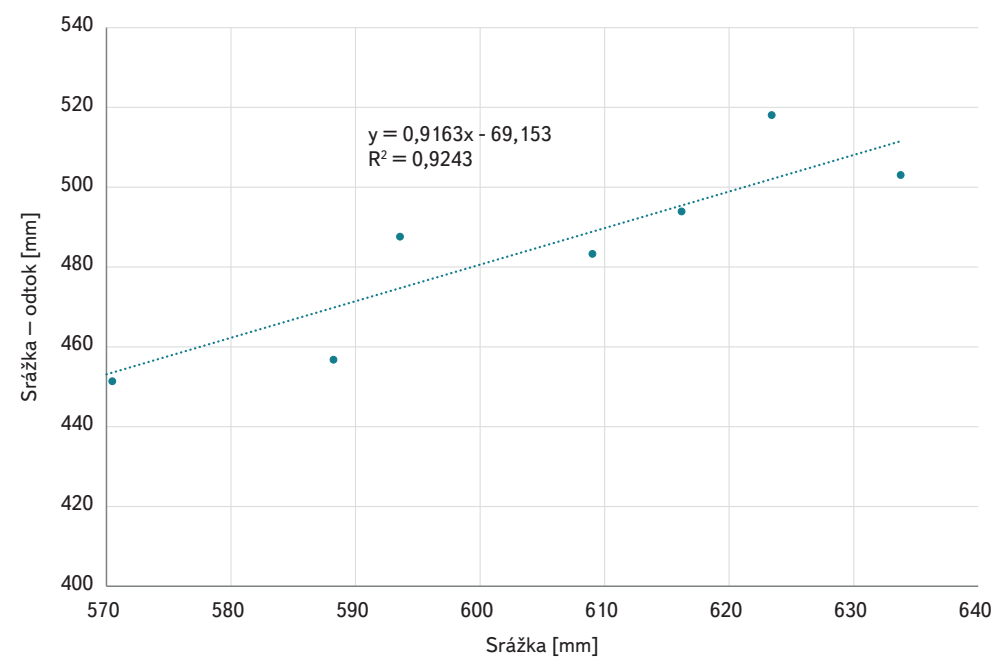

Obr. 8. Vztah územního výparu a srážky

Fig. 8. Relationship between evapotranspiration and precipitation

Po pátém roce pokračovalo sucho jen v období 1948-1954 a 2013-2020, v obou prípadech jsou v posledních letech vidět krátké, ale větší vzestupy odtoku nad průměrnou prahovou mez.

Údaje z tab. 3 jsou zpracovány ve formě korelačních grafů na obr. 7 a 8. Z grafů je zřejmé, že potenciální evapotranspirace předpokládaným zpưsobem vzrůstá s teplotou, ale vztah rozdílu srážek a odtoku (což je bilanční odhad územního výparu) k potenciální evapotranspiraci je velmi volný. Rozdíl srážek a odtoku je dominantně závislý na velikosti srážek. V období sucha, kromě zimních měsíců, je pro výpar dostatek energie, takže je omezován zejména velikostí srážek. 


\section{ZÁVĚR}

Ze zpracování výskytu případů hydrologického sucha v řadě průtoků Labe v Děčíně a srážek i teplot v povodí Labe v Děčíně z období 1851-2020 vyplynuly následující poznatky:

- Významná víceletá hydrologická sucha o trvání pět a více let se vyskytla v období 1861-1876 a pak až v období 1932-2020, což souvisí s dlouhodobým kolísáním průměrných srážek v povodí. Výskyty hydrologického sucha odpovídají obdobím, v nichž byly minimální víceleté prưměry srážek.

- Při setřídění prípadů hydrologického sucha podle trvání z dat vyplývá, že hydrologické sucho 2013-2020 bylo nejdelší ze všech období sucha od roku 1851. Trvalo téměř sedm let a také se vyznačuje největším celkovým nedostatkovým objemem (pod dlouhodobým průměrným průtokem). Při posouzení podle průměrného ročního nedostatkového objemu je však až na čtvrtém místě.

— V období sucha potenciální evapotranspirace vzrůstá s teplotou, ale vztah rozdílu srážek a odtoku (což je bilanční odhad územního výparu) k potenciální evapotranspiraci je velmi volný. Rozdíl srážek a odtoku je dominantně závislý na velikosti srážek. V období sucha, kromě zimních měsíců, je vlivem vysokých teplot vzduchu pro výpar dostatek energie. Výpar je proto omezen víceméně množstvím spadlých srážek, bez nichž už není, co by se vypařilo.

\section{Poděkování}

Vznik článku byl podpořen interním grantem VúV TGM 3600.52.28-2020

\section{Literatura}

[1] VLNAS, R. a kol. Časová a plošná variabilita hydrologického sucha v podmínkách klimatické změny na území České republiky. Praha: Výzkumný ústav vodohospodářský T. G. Masaryka, 2010. 160 s. ISBN 978-80-87402-11-5.

[2] BRÁZDIL, R., TRNKA, M. a kol. Historie počasí a podnebí v českých zemích XI: Sucho v českých zemích: minulost, současnost a budoucnost. Brno: Centrum výzkumu globální změny AV ČR, 2015. 402 s. ISBN 978-80-87902-11-0

[3] DAŇHELKA, J. a kol. Vyhodnoceni sucha na územi České republiky v roce 2015. Praha: Český hydrometeorologický ústav, 2015. Dostupné z: http://portal.chmi.cz/files/portal/docs/meteo/ok/ SUCHO/zpravy/Sucho_2015_CHMU_prosinec.pdf

[4] KAŠPÁREK, L., VLNAS, R., NESLÁDKOVÁ, M. VItavská kaskáda-podklady pro střednědobé plánování provozu prí málovodných obdobich. Praha: Výzkumná zpráva zpracovaná pro Povodí Vltavy, s. p., Praha: Výzkumný ústav vodohospodářský T. G. Masaryka, 2016. 37 s.

[5] DAŇHELKA, J. a kol. Sucho 2011-2018 sborník abstraktů. Praha: Český hydrometeorologický ústav, 2020, 42 s. IBSN 978-80-87577-91-2.

[6] ELLEDER, L., KAŠPÁREK, L., Š́ROVÁ, J., KABELKA, T. Low water stage marks on hunger stones: verification for the Elbe from 1616 to 2015. Climate of the Past [on-line], 2020, 16(5), 1821-1846 [vid. 202011-01]. ISSN 1814-9324. Dostupné z: doi:10.5194/cp-16-1821-2020

[7] KAŠPÁREK, L., VIZINA, A., KOŽÍN, R. Využití hydrologického modelu BILAN pro odhad změny schopnosti půdy zadržet vodu. Vodní hospodáŕství. 2017, roč. 67, s. 19-22

[8] KAŠPÁREK, L. Dlouhodobé kolísání průtoků VItavy v Praze. Vodohospodářské technicko-ekonomické informace, 2017, roč. 59, č. 5, s. 25-30

\section{Autoři}

Ing. Ladislav Kašpárek, CSc.

凶ladislav.kasparek@vuv.cz

ORCID: 0000-0002-8394-9136

Ing. Roman Kožín

凶roman.kozin@vuv.cz

ORCID: 0000-0002-5773-6567

Výzkumný ústav vodohospodářský T. G. Masaryka

Příspěvek prošel lektorským řizením.

DOI: 10.46555/VTEI.2021.03.002

\section{EXTREME MULTI-ANNUAL HYDROLOGICAL DROUGHTS IN THE ELBE RIVER BASIN}

\section{KAŠPÁREK, L., KOŽÍN, R.}

T. G. Masaryk Water Research Institute

Keywords: multi-annual hydrological drought Elbe - deficit volume - extremes

The aim of the study was the evaluation of multi-year hydrological droughts in the Elbe river basin for the Děčín stream gauging station (catchment area $51104 \mathrm{~m}^{2}$ ). Average monthly flows from period 1851-2000 are available for the station. For this period, we also compiled a series of average monthly precipitation and temperatures from several data sources. We calculated annual values for precipitation, temperatures and differences in annual precipitation and runoff, then we computed long-term averages and regression linear trends for change over time. The trends are only slightly upward for all three variables, but long-term fluctuations in precipitation are more significant. According to the quantified multi-year average flows and precipitation, we searched for and merged cases from which one continuous drought lasting at least 5 years is generated for both precipitation and runoff. We quantified deficit volumes for individual drought periods. The long-term average flow was chosen as the threshold flow. The hydrological drought 2013-2020 had the longest duration, almost 7 years, of all droughts since 1851 and was also characterized by the largest total deficit volume. When compared to the average annual deficit volume, it is only in fourth place. When comparing the time series of monthly flows, it turned out that cases from different periods have similar patterns and behavior. 